\title{
SPATIO-TEMPORAL DIFFERENCES OF SEDIMENT ACCUMULATION RATE IN THE LAKE GOŚCIĄŻ (CENTRAL POLAND) AS A RESPONSE OF METEOROLOGICAL CONDITIONS AND LAKE BASIN MORPHOMETRY
}

\author{
MICHAŁ FOJUTOWSKI*, PIOTR GIERSZEWSKI, DARIUSZ BRYKALA, \\ ALICJA BONK, MIROSŁAW BLASZKIEWICZ, MATEUSZ KRAMKOWSKI
}

Department of Environmental Resources and Geohazards, Institute of Geography and Spatial Organization, Polish Academy of Sciences, Poland.

\begin{abstract}
Weather conditions and lake basin morphometry are of key importance in the study of sediment accumulation rate in lakes. This study aims to determine how these factors affect spatial and seasonal variations in sedimentation rate in the epilimnion and hypolimnion of Lake Gościąż. To determine sedimentation rates, six sedimentation traps were set up at different locations and depths in the lake. Weather data were obtained from a meteorological station near the lake. Furthermore, temperature in the lake water column was measured continuously, and during field work oxygenation and transparency were also measured. Seasonal changes in sediment composition were analyzed on smear slides under microscope. The study showed that sedimentation rate increased as bottom steepness increased, and that there was more sediment in the hypolimnion than the epilimnion, especially in spring and autumn. There was a clear seasonal variation in early-spring and autumn peaks in sedimentation. The obtained results were significantly dependent on bottom relief, wind and air temperature through these factors' influence on water temperature. The results show that the sediment accumulation rate in Lake Gościąż depends on the hydrodynamic conditions, which are determined by wind speed, wind direction, water temperature, and the shape and steepness of the lake basin. The relief features of the lake bottom and its orientation relative to the prevailing wind are significant factors in the spatial differentiation in sediment accumulation rate and composition of sedimenting material. It has been shown that the lake's shallow-water zone (littoral and sublittoral) is an important source of the material accumulated in the profundal zone. The patterns and mechanisms of the course of contemporary sedimentation in Lake Gościąż, as determined based on the conducted investigations, can be applied in the study of other lakes and in assessing the representativeness of sampling sites for laminated bottom sediments to be used in palaeo-environmental studies.
\end{abstract}

Diferencias espacio temporales de la tasa de acumulación de sedimentos en el lago Gościąż (Polonia central) como respuesta a las condiciones meteorológicas y a la morfometría del lago

RESUMEN. Las condiciones meteorológicas y la morfometría de la cuenca son clave en el estudio de las tasas de sedimentación en lagos. Este trabajo tiene como objetivo analizar cómo estos factores afectan a las variaciones espaciales y estacionales de la tasa de sedimentación en el epilimnion y el hipolimnion del lago Gościąż. Para determinar las tasas de sedimentación, se instalaron seis trampas de sedimentos en diferentes localizaciones dentro del lago y a diferentes profundidades. Los datos meteorológicos se obtuvieron de una estación próxima al lago. Además, se midió de manera constante la temperatura de la columna de agua y, durante campañas de campo, su grado de oxigenación y transparencia. Se analizaron cambios estacionales en la composición del sedimento mediante frotis para microscopio. El estudio indica que la tasa de sedimentación incrementó conforme la pendiente 
del fondo del lago aumentaba, y que había más sedimento en el hipolimnion que en el epilimnion, especialmente en verano y en otoño. Se observó una clara variación estacional en los picos de sedimentación al principio de la primavera y en otoño. Los resultados dependieron significativamente del relieve del fondo del lago, del viento y de la temperatura del aire, que a su vez influenciaron la temperatura del agua. Los resultados muestran que la acumulación de sedimento en el Lago Gościąż depende de las condiciones hidrodinámicas, las cuales están determinadas por la velocidad y dirección del viento, la temperatura del agua y la pendiente del fondo del lago. Las características del relieve del fondo del lago y su orientación relativa a los vientos predominantes son factores significativos que explican la diferenciación espacial de la tasa de sedimentación y la composición del material sedimentado. Las zonas someras del lago (litorales y sublitorales) son una fuente importante de sedimento del material acumulado en la zona profunda. Los patrones y mecanismos de la sedimentación contemporánea del lago Gościąż, definidos en este trabajo pueden ser aplicados al estudio de otros lagos, así como en la evaluación de la representatividad de sitios de muestreo para sedimentos laminados en estudios paleoambientales.

Key words: Lake morphometry, dimictic lake, sediment resuspension, sediment accumulation rate, hydrometeorological monitoring.

Palabras clave: Morfometría lacustre, lago dimíctico, resuspensión de sedimentos, tasa de acumulación de sedimento, seguimiento hidrometeorológico.

Received: 10 June 2020

Accepted: 30 October 2020

* Corresponding author: Michał Fojutowski, Department of Environmental Resources and Geohazards, Institute of Geography and Spatial Organization, Polish Academy of Sciences, Kopernika 19, PL87100 Toruń, Poland. E-mail address: mfojutowski@twarda.pan.pl

\section{Introduction}

Lake sediments are excellent archives of changes taking place in the natural environment, because lakes react very quickly to changes in their surroundings (Vos et al., 1997). Of particular usefulness in this regard are annually laminated sediments, i.e. varves, which show regional and local changes at high-resolution (Segerstrom et al., 1984; Goslar, 1993; Leeman and Niessen, 1994; Schaller et al., 1997; Moore et al., 2001; Schettler et al., 2006; Ojala et al., 2008; Kaal et al., 2015; Zolitschka et al., 2015; Bonk et al., 2016; Ott et al., 2017) but are relatively rare (Tylmann, 2011; Ojala et al., 2012; Zolitschka et al., 2015). Anaerobic conditions at the lake bottom are required for the preservation of varves, as confirmed by the fact that they coincide spatially with bottom areas covered by the hypolimnion in dimictic lakes or the monimolimnion in meromictic lakes (Petterson et al., 1993; Tylmann et al., 2012; Salminen et al., 2019). Therefore, the potential drivers of annual lamination discontinuity or its absence are syn- and metasedimentary disturbances to the sediment (O'Sullivan, 1983) caused by dwelling organisms, strong winds leading to intense water column mixing or a deeplying thermocline (Horppila and Niemistö, 2008).

In order to fully exploit the information on environmental changes preserved in laminated sediments, and thus to create a reliable and accurate chronology, it is necessary to understand the mechanisms affecting the formation of these sediments (Lotter and Birks, 1997; Bonk et al., 2015). For this, monitoring of contemporary lake sediments, which reflect current seasonal changes, is an excellent tool. Observing changes requires sediment traps, as well as monitoring of the meteorological and hydrological conditions in the catchment (Leeman and Niessen, 1994; Ojala et al., 2014). Sediment traps are a fairly common limnological research method but in the study of annually laminated lake sediments, 
their popularity is relatively recent, and is still growing (Flower, 1990; Mieszczankin, 1997; Bluszcz et al., 2008; Bonk et al., 2015; Kienel et al., 2017; Maier et al., 2018; Johansson et al., 2019). The results of this type of research are difficult to integrate with morphometric and meteorological conditions, and hence it is relatively rarely done. The basic research involves capturing suspended matter (also known as "seston" [Ruttner, 1963]) in the lake's water; this is a component of the lake's primary production and a supply of allochthonous material (Wetzel et al., 1972; Gasith, 1976). Primary production can affect the amount of sediment directly by biological particles, and indirectly through calcium carbonate precipitating in biogeochemical processes (Groleau et al., 2000). The biological production volume in the lake is affected most strongly by nutrient supply (Pace and Lovett, 2013). Meteorological impacts are usually taken into consideration less frequently in studies of lake productivity, although they are becoming more important as climate conditions change dynamically and human impact increases. Factors related to meteorological conditions may also affect the redistribution of plankton within the lake and sediment resuspension, especially in very shallow parts (Dearing, 1997). The spatial diversity of sedimentation is also influenced by lake basin morphology, i.e. the steepness of the lake basin slopes and the number and arrangement of the basins composing the water body (Punning et al., 2004).

Lake Gościąż is widely known for its annually laminated lake sediments, which occur throughout almost the entire sediment profile of the deepest part of the lake (Ralska-Jasiewiczowa et al., 1998). Only recently, a detailed investigation of varve microfacies combined with multiproxy dating techniques have allowed a new chronology to be developed for the Lake Gościąż sediment record, establishing the onset of lacustrine sedimentation in the late Allerød at 12,844 +213/-311 varve yrs BP (Bonk et al., 2021; Müller et al., in press). Studies of contemporary sedimentation using sediment traps were first used in Lake Gościąż in 1988. Further studies were performed in 1991 (Kentzer and Żytkowicz, 1993) and in 1993-95 (Mieszczankin, 1997). They were conducted to analyse sediment composition (content of $\mathrm{N}, \mathrm{P}, \mathrm{CaCO}_{3}$, organic matter and plant pollen), differentiation of sedimentation rate in the water column, and seasonal variability of sedimentation rate (Kentzer and Żytkowicz, 1993; Mieszczankin and Noryśkiewicz, 2000). Research conducted in the 1990s showed that the sedimentation rate in Lake Gościąż is as much as several times higher than in other lakes with annually laminated sediments, and these differences result from its higher trophy and large contribution of resuspended matter (Mieszczankin, 1997). These studies were conducted using material collected from sediment traps located along a north-south axis. Our research analysed the course of sedimentation in an east-west transect, along the lake's longer axis and the prevailing wind direction. Thus, only the results of the analysis of the sedimentation rate at the site in the deepest part of the lake will be comparable.

The main objective of the presented research is to recognise the determinants of the course of contemporary sedimentation and the qualitative composition of sedimenting material. This study therefore aims to show the impact of meteorological factors and basin topography on the spatial differentiation of the sediment accumulation rate in the lake's epilimnion and hypolimnion. This issue will be presented against the seasonal variability in deposited matter. To achieve this goal, complementary meteorological and hydrological monitoring, which has not been conducted in the Lake Gościąż catchment area before, was carried out.

\section{Material and methods}

\subsection{Study area}

Lake Gościąż is located in the Gostynin Lakeland (Central Poland) at an elevation of $64.3 \mathrm{~m}$ a.s.l. (Fig. 1). The lake is located in a widening in the valley of the lower (lowland) course of the Vistula River (the longest river in Poland). This area was initially formed under the influence of glacial erosion and, later, fluvioglacial and fluvial erosion. The coexistence of accumulation and erosion processes led to the deposition of a series of sandy-gravelly sediments with an average thickness of 40$45 \mathrm{~m}$ (Skompski, 1969). The area's relief was shaped during the Weichselian glaciation and the 
Holocene. Its essential features are subglacial channels and fluvioglacial terraces (Wiśniewski, 1976). Sandy dunes created by aeolian activity in the Late Glacial are also abundant in this area (Urbaniak, 1967; Rychel et al., 2018; Kruczkowska et al., 2020). Lake Gościąż lies at the bottom part of a subglacial channel that developed during the recession of the Last Glacial ice sheet around 18,000 years ago. The lake formation started during the transition from Bølling to Allerød as a result of dead ice melting (Ralska-Jasiewiczowa et al., 1998). The properties of the relief and geological structure allow the Vistula's valley and bed to maintain hydrogeological connections to their adjacent areas. In such conditions, subglacial channels whose course runs vertically relative to the direction of groundwater flow are fed by groundwaters of local and regional circulation system (Gierszewski, 2000). In combination with other environmental features (including the poorly-varied subsoil lithology, high afforestation, and low human impact on the environment), this ensures that Lake Gościąż receives a steady supply of groundwater of relatively stable chemical composition, which in turn also results in a steady amount of sedimentation and stable sediment characteristics.

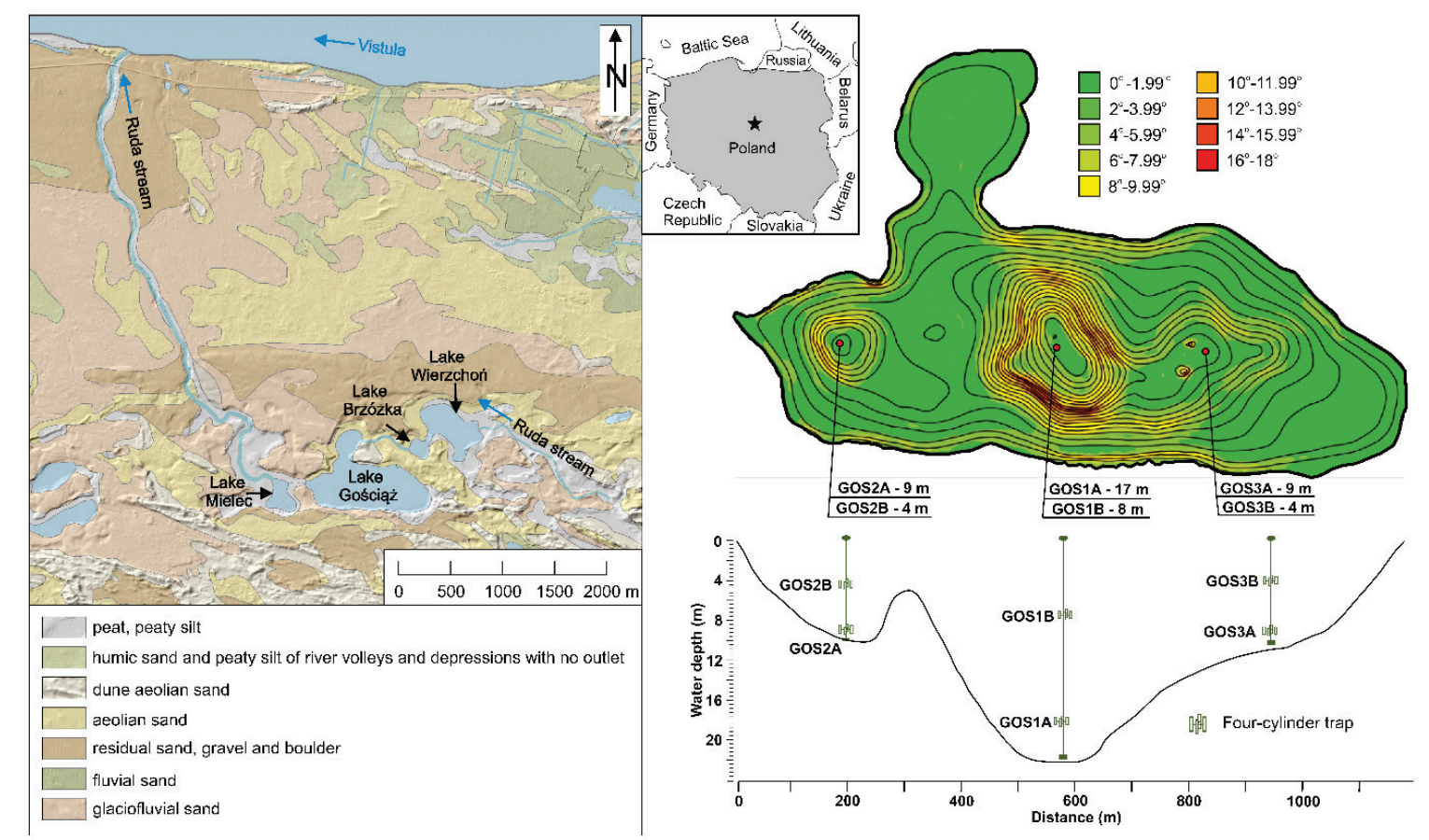

Figure 1. Location of the study area and the bathymetry and slope steepness map of Lake Gościaż with marked locations of sediment traps (geological background of the Lake Gościąz catchment area on the basis of Rychel et al., 2014).

The climate in this area is classified as cold temperate with warm summers (Peel et al., 2007). According to data from $1967-2015$, the annual average temperature is $8.2^{\circ} \mathrm{C}$, while the average sum of precipitation is $533 \mathrm{~mm}$ (Bartczak et al., 2019). The growing period lasts 210-215 days (Demidowicz et al., 1998). Westerly winds prevail in this area (Woś, 1999).

The lake catchment area is covered with pine forests. There are communities of Querco roborisPinetum wetter habitats, and Peucedano-Pinetum in drier locations (Kępczyński and Noryśkiewicz, 1998). There is a community of Carici elongatae-Alnetum sensu lato immediately around the lake, and a Tilio-Carpinetum community slightly further away. On submerged shores there are also brushwood communities represented by Salicetum pentandro-cinereaes. Aquatic vegetation inhabits the shallowest parts of the lake, especially in the shallow bay to the north. This vegetation is represented mainly by communities of Lemno-Spirodeletum polyrrhizae, Hydrocharitetum morsus-ranae, Elodeetum Canadensis and Potamogetonetum pectinati, and less commonly by Potamogetonetum filiformis, and 
also, at the south-western shore of the lake, by Potamogetonetum perfoliati. The slightly silty littoral parts of Gościąż Lake are overgrown with reedswamps. The largest areas are occupied by Phragmitetum communis and Typhetum angustifoliae. Smaller areas are occupied by Glycerietum maximae, Eleocharitetum palustris and Acoretum calami (Kępczyński and Noryśkiewicz, 1993).

Lake Gościąż is small $\left(0.417 \mathrm{~km}^{2}\right)$ and relatively deep (maximum depth $\left.22.1 \mathrm{~m}\right)$ (Table 1). It consists of two basins: a shallow northern one (Tobyłka Bay) and a main one with two clearly distinguished sub-basins. The lake is deepest in the middle (Fig. 1). Along with three other lakes Mielec, Brzózka and Wierzchoń - Lake Gościąż forms a lake system called "Na Jazach", which is connected by the stream Ruda. In the middle course of the stream, below Lake Gościąż, there is a weir that has existed in its present form since 1989 and is a remnant of a mill built in the 16th century. The groundwater watershed of the catchment area is $56 \mathrm{~km}^{2}$, of which $39 \mathrm{~km}^{2}$ is endorheic (Glazik, 1978; Gierszewski, 2000). The lakes in the studied catchment area are fed primarily (ca. 90\%) by groundwater, mainly from the south (Gierszewski, 2000). The groundwater supplying the Lake Gościąż is of Ca$\mathrm{HCO}_{3}-\mathrm{SO}_{4}$ type, with low mineralisation (averaging $260 \mathrm{mg} \cdot \mathrm{dm}^{-3}$ ) (Gierszewski,, 2000; 2001). The biogeochemical changes in the lake have a slight effect - a decrease of $20 \mathrm{mg} \cdot \mathrm{dm}^{-3}$ in the total mineralisation of the water, mainly seen in lower concentrations of $\mathrm{Ca}$ and $\mathrm{SO}_{4}$ ions. As a result, the ionic type of the water also changes to $\mathrm{Ca}-\mathrm{Mg}-\mathrm{HCO}_{3}$. The supply of nutrients in the groundwater exceeds safe thresholds for the harmonious functioning of the lake. In the years 1991-93 this averaged about $3 \mathrm{~g}$ $\mathrm{P} \mathrm{m}^{-2}$ and about $40 \mathrm{~g} \mathrm{~N} \mathrm{~m}^{-2}$. The N:P ratio of 14:1 indicates that in terms of fertility, Lake Gościąż is eutrophic (Giziński et al., 1998).

Table 1. Morphometric parameters of the Lake Gościąż.

\begin{tabular}{|c|c|}
\hline Location & $52^{\circ} 34 ' 58^{\prime \prime} \mathrm{N} 19^{\circ} 20^{\prime} 23^{\prime} ' \mathrm{E}$ \\
\hline Water level (m a.s.1.) & 64.3 \\
\hline Surface $\left(\mathrm{km}^{2}\right)$ & 0.417 \\
\hline Maximum length (m) & 1180 \\
\hline Maximum width (m) & 723 \\
\hline Medium width (m) & 357 \\
\hline Maximum depth (m) & 22.1 \\
\hline Average depth (m) & 5 \\
\hline Elongation indicator (m) & 1.59 \\
\hline Shoreline length (m) & 3452 \\
\hline Development of the coastline & 1.51 \\
\hline Capacity $\left(\mathrm{m}^{3}\right)$ & 2073000 \\
\hline
\end{tabular}

The lake freezing period averages about 75 days in this region (Choiński et al., 2015). In terms of mixing, Lake Gościąż represents a bradimictic type (Churski and Marszelewski, 1998). The lake has a well-developed summer stratification, with a distinct thermocline with a strong gradient of $3.5^{\circ} \mathrm{C} \mathrm{m}^{-1}$. At the same time, the level of oxygenation diminishes steadily down though the water column (Gierszewski, 2000). The deoxygenated waters of the hypolimnion have a higher concentration of $\mathrm{Ca}^{2+}$ $(25 \%), \mathrm{HCO}_{3}{ }^{2-}, \mathrm{NH}_{4}{ }^{+}$and $\mathrm{PO}_{4}{ }^{3-}$ ions. However, the concentration of $\mathrm{SO}_{4}(20 \%)$ and the $\mathrm{pH}$ of the water are significantly lower. The chemical properties of the water in Lake Gościąż (in addition to the assimilation of biogenic substances by aquatic organisms) is transformed by changes related to the functioning of the carbonate system and redox reactions (Gierszewski, 2000). 
Due to its morphological and hydrobiological features, Lake Gościąż has two zones with different water dynamics: a shallow-water zone (to a depth of 5-6 m), which covers about $50 \%$ of the lake's bottom surface, and a deep-water zone. The bottom sediments in the polymictic shallow-water zone are subject to frequent redeposition and displacement towards the middle of the lake. The highest accumulation of sediments occurs in the deep-water zone, which is static and deoxygenated during the summer stratification (Giziński et al., 1998). The studies conducted in the 1990s showed the mean sedimentation rate to be $5.9 \mathrm{~g} \mathrm{~m}^{-2} \mathrm{~d}^{-1}$ in the epilimnion and $13.1 \mathrm{~g} \mathrm{~m}^{-2} \mathrm{~d}^{-1}$ in the hypolimnion (Mieszczankin, 1997). The maxima occurred during overturn, and the minima in summer stratification periods. The low summer sedimentation rate is conditioned by the thermocline, which is a natural barrier to the sedimentation of matter. The greater sedimentation in traps in the hypolimnion, especially during overturns, is associated with resedimentation processes, and during summer stratifications should be connected with the "funnel effect". The most important component of sediment was $\mathrm{CaCO}_{3}$ (Giziński et al., 1998).

\subsection{Sampling and analyses}

Sediment samples were collected from August 2017 till May 2019 at four- to seven-week intervals except for periods of ice cover on the lake. The research was carried out using sediment traps at three different points in the lake (GOS 1, GOS 2 and GOS 3) (Fig. 1). At each, two sediment traps were installed: one in the lower epilimnion (traps GOS 1B, 2B and 3B) and the other in hypolimnion above the bottom (traps GOS 1A, 2A and 3A). Each trap consisted of four cylinders of $8 \mathrm{~cm}$ in diameter and $50 \mathrm{~cm}$ high. In the deepest part of the lake (GOS 1) thermal monitoring was also conducted using a HOBO Water Temperature Pro v2 Data Logger. The water temperature was measured at 30-minute resolution at depths of $0,1,2,3,4,5,6,7,8,9,10,12,14,18$ and $20 \mathrm{~m}$. During each sediment traps receiving, a Secchi disc was also used to measure water transparency, and in the period from July 2017 to December 2018, a Hanna HI 9829 multiparametric meter was also used to measure the dissolved oxygen content at the lake's deepest point (GOS 1), from the surface down to the bottom. In 2017, bathymetric measurements of the lake were taken with a Lowrance HDS-7 echosounder.

The course of weather conditions was recorded using a HOBO RX300 Station - CELL-3G automatic weather station at $2 \mathrm{~km}$ from the lake. The station records the following parameters hourly: air temperature, precipitation, and direction, speed and gusts of wind. Lake water levels were recorded every 0.5 h using a HOBO U20-001-04 water level recorder.

To determine dry weight of sediment, the material from sediment traps was centrifuged and dried for $24 \mathrm{~h}$ at $105^{\circ} \mathrm{C}$, and then weighted to an accuracy of $0.001 \mathrm{~g}$. Mean sediment-accumulation rate was expressed in grams of dry matter per square metre per day $\left(\mathrm{g} \mathrm{m}^{-2} \mathrm{~d}^{-1}\right)$.

To determine the quantitative composition, sediment samples were analysed for the content of organic matter, calcium carbonate, and biogenic and terrigenous silica. Organic matter content was determined by roasting of the sample for 4 hours at $550^{\circ} \mathrm{C}$ (Heiri et al., 2001), and calcium carbonate by the Scheibler method. Biogenic silica concentration was calculated as the difference in weight between total silica content and the share of terrigenous silica. Total silica was determined after dissolution of acid-soluble fractions and organic matter in $\mathrm{H}_{2} \mathrm{SO}_{4}$, and the terrigenous silica was the residue after removal of opaline (biogenic) silica from the total silica with $0.5 \mathrm{n} \mathrm{NaOH}$ in a water bath at $100^{\circ} \mathrm{C}$ for 2 hours (Bechtel et al., 2007). The difference between $100 \%$ and the total sum of organic matter, $\mathrm{CaCO}_{3}$, terrigenous and biogenic silica represents "mineral residue" (MR). The "mineral residue" includes hot-acid-extractable compounds excluding carbonates (e.g. sulphides, some clay minerals, etc.) (Woszczyk et al., 2009). 
Prior to smear slide preparation, 66 fresh sediment trap samples were transferred to a microscope slide and dried on a heating plate. Then, a cover slip was placed on the dried sediment using glycerine. Ready smear slides were analysed under a light microscope at $20 \times$ to $200 \times$ magnification to track the seasonal changes within the sediment components. This analysis is only a semi-quantitative analytical tool, but it provides insights into the sediment components and allows to recognize a relative change in lithology (Schnurrenberger et al., 2003). The components of material retrieved from sediment traps can be grouped in three categories: organic, diatoms and carbonates.

The twenty-month-long measurement period of water temperature made it possible to construct depth profiles of water temperature (Surfer Software) for the deepest part of the lake (GOS 1). The data from bathymetric measurements were next converted into numerical .csv files, which were processed by Arc GIS version 10.2.2 software (ESRI 2014) to generate a bathymetric map and a map of bottom slope steepness. The bathymetric data were used to calculate the morphometric parameters of the lake basin.

\section{Results}

\subsection{Sediment accumulation rate}

Mean sediment accumulation rate in each of the three monitored locations was higher in the traps in the hypolimnion (deeper trap). In the epilimnion traps, the accumulation varied from $0.94 \mathrm{~g} \mathrm{~m}^{-2} \mathrm{~d}^{-1}$ to $5.95 \mathrm{~g} \mathrm{~m}^{-2} \mathrm{~d}^{-1}$ (Fig. 2). The lowest sediment accumulation rate for traps GOS 1B and GOS 3B were measured in winter 2018-19 and reached only $1.24 \mathrm{~g} \mathrm{~m}^{-2} \mathrm{~d}^{-1}$ and $1.18 \mathrm{~g} \mathrm{~m}^{-2} \mathrm{~d}^{-1}$, respectively. In trap GOS 2B, the accumulation rate was lowest between 27 July and 25 August 2017, and amounted to $0.94 \mathrm{~g} \mathrm{~m}^{-2} \mathrm{~d}^{-1}$. The largest amount of sediment was accumulated in trap GOS 1B between 13 July and 13 August 2018 (4.24 $\left.\mathrm{g} \mathrm{m}^{-2} \mathrm{~d}^{-1}\right)$, in GOS 2B between 26 August and 9 October $2017\left(5.95 \mathrm{~g} \mathrm{~m}^{-2} \mathrm{~d}^{-1}\right)$, and in GOS 3B between 14 March and 11 April $2019\left(4.54 \mathrm{~g} \mathrm{~m}^{-2} \mathrm{~d}^{-1}\right)$. In the traps located in the hypolimnion, the sediment accumulation rate varied from $1.93 \mathrm{~g} \mathrm{~m}^{-2} \mathrm{~d}^{-1}$ to $10.21 \mathrm{~g} \mathrm{~m}^{-2} \mathrm{~d}^{-1}$. The lowest accumulation rate in GOS $1 \mathrm{~A}$ was measured between 25 May and 12 July $2018\left(1.93 \mathrm{~g} \mathrm{~m}^{-2} \mathrm{~d}^{-1}\right)$, whereas in traps GOS 2A and GOS 3A, it was between 5 December 2018 and 13 March $2019\left(2.17 \mathrm{~g} \mathrm{~m}^{-2} \mathrm{~d}^{-1}\right.$ and $1.46 \mathrm{~g} \mathrm{~m}^{-2} \mathrm{~d}^{-1}$, respectively). In GOS 1A, the sediment accumulation rate was highest between 10 October and 10 November 2017, and reached $10.21 \mathrm{~g} \mathrm{~m}^{-2} \mathrm{~d}^{-1}$. In GOS 2A and GOS 3A it was the highest from 14 March till 11 April 2019, amounting up to $8.28 \mathrm{~g} \mathrm{~m}^{-2} \mathrm{~d}^{-1}$ and $6.47 \mathrm{~g} \mathrm{~m}^{-2} \mathrm{~d}^{-1}$, respectively. There is no data on the course of sedimentation in the GOS 1A and GOS 2B traps from October 2018 to April 2019 and in the GOS 3A trap from May 2018 to October 2018 because the traps disappeared. It should also be noted that the results obtained for April 2018 (containing sedimentation material from the winter season) are a value averaged over the five-month period. Therefore, these samples contain material from the end of the autumn overturn, the winter and early spring. Mean sediment accumulation rate in the deepest location (GOS 1) was 71\% higher in the hypolimnion than in the epilimnion. In the western location (GOS 2), the difference reached $57 \%$ in favour of the deeper trap, while in the eastern part of the lake (GOS 3) it was only $29 \%$. In the deepest lake sub-basin (near GOS 1), slope steepness on the south-western side is up to $18^{\circ}$ (Fig. 1). In the western part (near GOS 2), it is up to $14^{\circ}$, while in the eastern part (near GOS 3), where sedimentation values are the lowest, slope steepness does not exceed $4^{\circ}$. In the hypolimnion, the trap in the western part (GOS 2A) accumulated on average $41 \%$ more sediment than the one in the eastern part (GOS 3A), while in the deepest part of the lake (GOS 1A) the western trap averaged 38\% more than the eastern trap (GOS $3 \mathrm{~A})$. In the traps in the epilimnion, the average sediment accumulation rate was $16 \%$ higher in the western part of the lake (GOS 2B) than in the eastern part (GOS 3B), and in the deepest part (GOS 1B) it was 5\% higher than in the east (GOS 3B). 
Fojutowski et al.

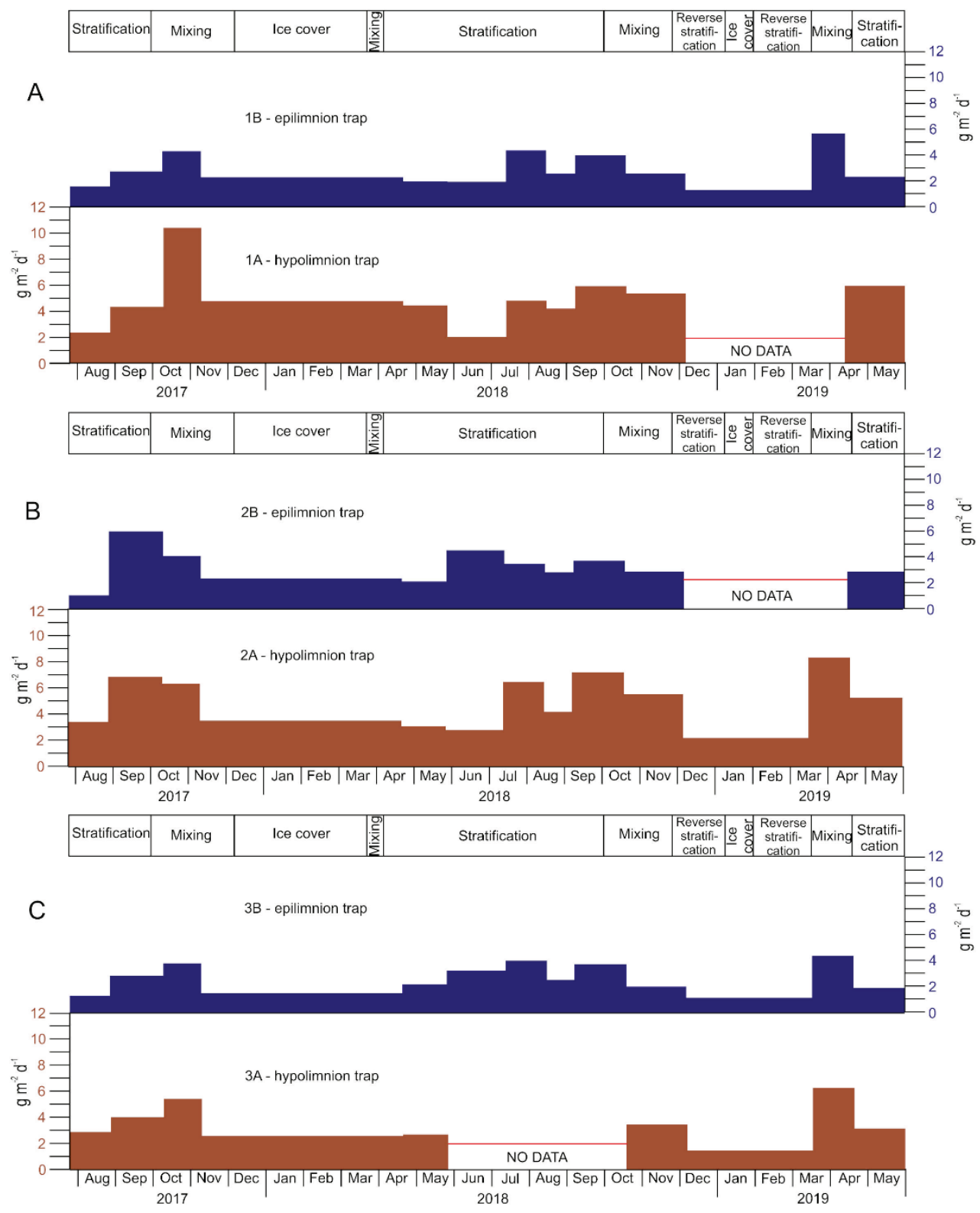

Figure 2. Sediment accumulation rate in Lake Gościqż: A - sediment traps GOS1A and $1 B ; B$ - sediment traps

GOS2A and 2B; C-sediments traps GOS3A and 3B. No data $1 A$ (December 2018 - April 2019), $2 A$

(December 2018 - April 2019), 3B (May 2018 - October 2018); D - air temperature (blue line), precipitation (orange line) and time of the sediment trap retrieving (black bars); $E$-variability in thermal conditions at the deepest site in Lake Gościaż. 

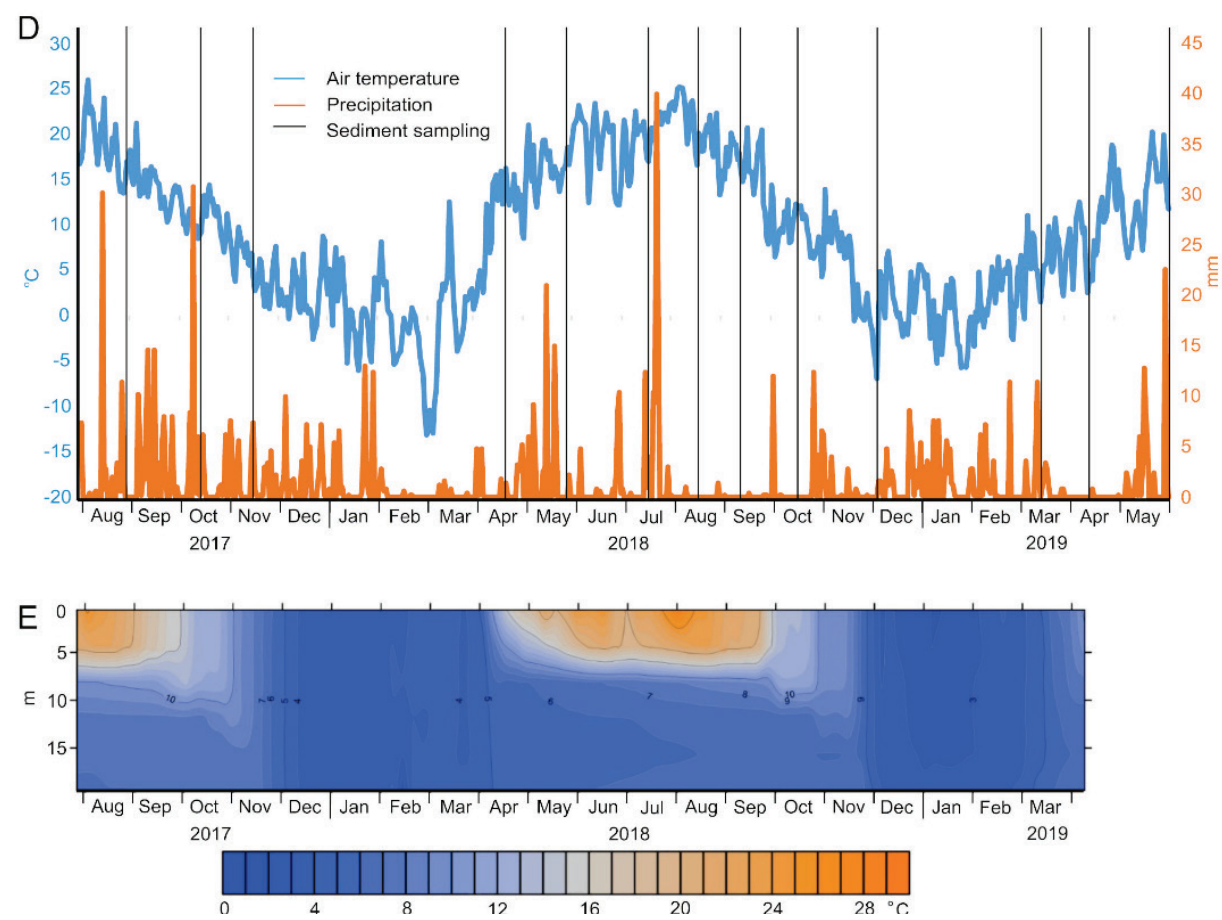

Figure 2. Sediment accumulation rate in Lake Gościąz: $A$ - sediment traps GOS1A and $1 B ; B$ - sediment traps GOS2A and 2B; C-sediments traps GOS3A and 3B. No data 1A (December 2018 - April 2019), $2 A$ (December 2018 - April 2019), 3B (May 2018 - October 2018); D - air temperature (blue line), precipitation (orange line) and time of the sediment trap retrieving (black bars); E-variability in thermal conditions at the deepest site in Lake Gościąz. (cont.)

\subsection{Meteorological conditions}

The highest air temperature in the study period was $35.3^{\circ} \mathrm{C}$, recorded on 9 August 2018, whereas the lowest value was $-19.6^{\circ} \mathrm{C}$, recorded on 27 February 2018. Mean daily temperatures (Fig. 2D) varied from $26.0^{\circ} \mathrm{C}$ (1 August 2017) to $-13.1^{\circ} \mathrm{C}(26$ February 2018). The highest monthly precipitation of 103.4 $\mathrm{mm}$ was observed in July 2018, compared to only $1 \mathrm{~mm}$ in April 2019. Daily precipitation was the highest on 18 July 2018 (40 mm).

The prevailing winds were southerly (26.9\%), south-westerly $(21.9 \%)$, northerly $(18.2 \%)$, and north-westerly $(15.6 \%)$. In autumn and winter, we detected markedly higher contributions of southerly winds $\left(157.5^{\circ}-202.5^{\circ}\right)$, with up to $51.6 \%$ in October 2017 , and south-westerly winds $\left(202.5^{\circ}-247.5^{\circ}\right)$, with up to $36.9 \%$ in December 2018. In spring and summer of each year, winds were mostly northerly $\left(337.5^{\circ}-22.5^{\circ}\right)$, north-westerly $\left(292.5^{\circ}-337.5^{\circ}\right)$, and westerly $\left(247.5^{\circ}-292.5^{\circ}\right)$ (Fig. 3). Generally, during the studied seasons, winds along the NE-SW axis dominated from September till April. Particularly conspicuous was the dominance of winds from the directions $180^{\circ}-270^{\circ}$, which in October-November 2017 reached as much as $85 \%$ of the total. In the summer half-year (April-October), the dominant wind directions were $270^{\circ}-360^{\circ}$, as their percentage contributions were then around $70 \%$, with up to $78 \%$ in May-July 2018. The average wind speeds in individual measurement series ranged from $0.58 \mathrm{~m} \mathrm{~s}^{-1}$ (AugSept 2018) to $0.85 \mathrm{~m} \mathrm{~s}^{-1}$ (Mar-Apr 2019) (Table 2). However, in terms of their impact on the lake-water hydrodynamics, momentary wind speeds - gust speeds - are important. Longer periods of wind with higher gust speeds were found in October 2017, March, June, July and October 2018, and March 2019. The maximum wind speed values measured ranged from 6 to $13.1 \mathrm{~m} \mathrm{~s}^{-1}$. 
Fojutowski et al.

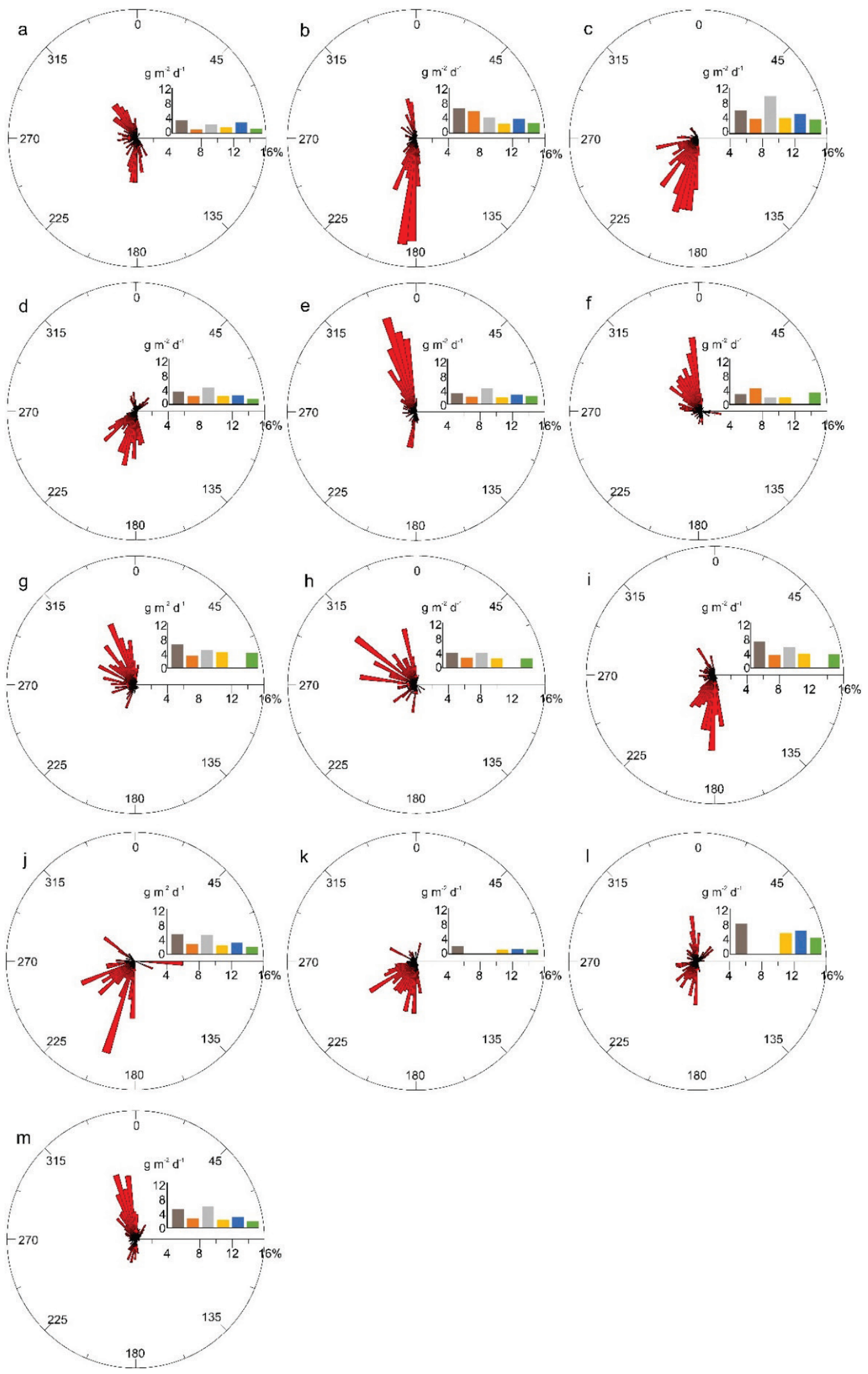

Figure 3. Wind direction: $a$ - 27 July 2017- 25 Aug 2017; b- 25 Aug 2017 - 9 Oct 2017; c - 9 Oct 2017-10 Nov 2017; d-10 Nov 2017-19 Apr 2018; e-19 Apr 2018-25 May 2018; f- 25 May 2018-12 Jul 2018; g- 12 Jul 2018-13 Aug 2018; $h$ - 13 Aug 2018-7 Sep 2018; i- 7 Sep 2018-15 Oct 2018; j- 15 Oct 2018-4 Dec 2018; $k-4$ Dec 2018-13 Mar 2019; l-13 Mar 2019-11 Apr 2019; m - 11 Apr 2019-30 May 2019; Sediment traps: brownGOS 1A, orange - GOS 1B, gray - GOS $2 A$, yellow - GOS $2 B$, blue - GOS 3 A, green - GOS $3 B$. 


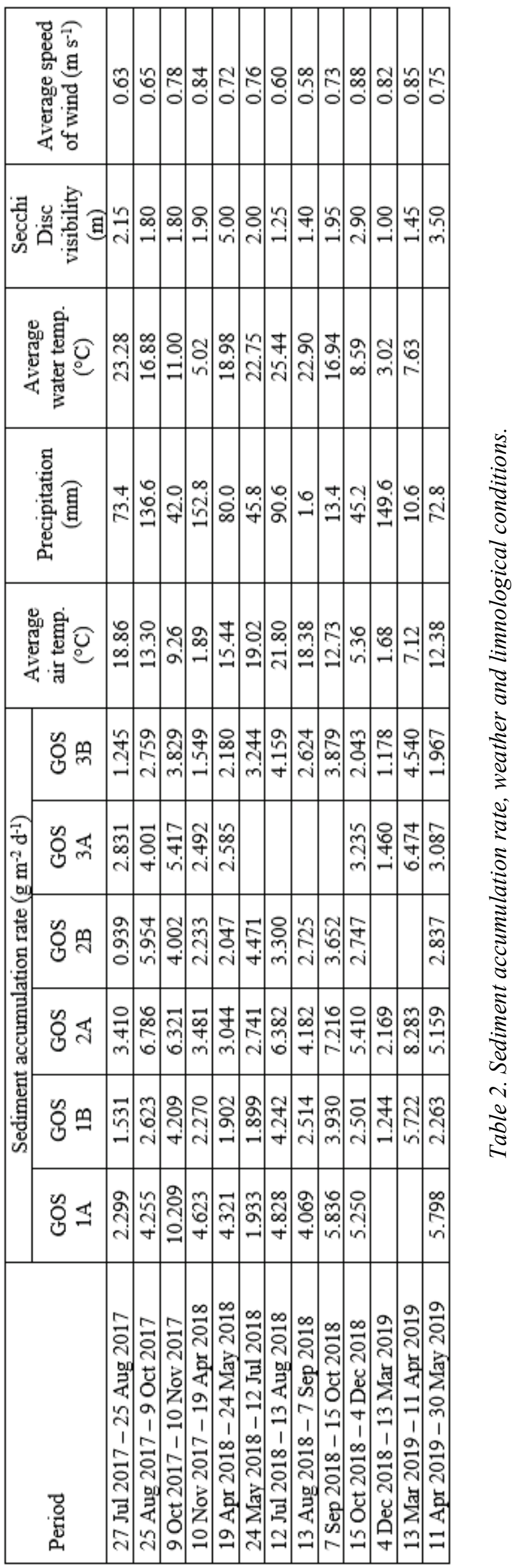




\subsection{Limnological conditions}

The amplitude of water level fluctuations in Lake Gościąż in the period from July 2017 to May 2019 was $40 \mathrm{~cm}$. In the first (incomplete) monitoring season (from July 2017), a thermal stratification was developed until the end of September 2017 (Fig. 2E). At the beginning of October 2017, the autumn mixing began. The water column mixed fully in the second half of November 2017. At the beginning of December 2017 an ice cover appeared on the lake and lasted until mid-March 2018. During this time, reverse stratification was observed. After the ice cover melted, the spring mixing took place. The first days of May 2018 showed the beginning of stratification, which progress was briefly interrupted by a cooling mid-month when the air temperature during the day did not exceed $20^{\circ} \mathrm{C}$. In the second half of June 2018, the water temperature in the epilimnion fell again, caused by the onset of a sharp chill. Within an hour, the air temperature dropped dramatically by $15^{\circ} \mathrm{C}$, and did not exceed $16^{\circ} \mathrm{C}$ for next several days. In the first decade of July 2018 , the temperature of the surface layer rose again and remained stable until the second half of September 2018. During the thermal stratification of the lake, the hypolimnion was completely anoxic, as recorded in measurements of oxygen concentration in the water (Fig. 4A). In May 2018, a total oxygen deficit was found from a depth of $10 \mathrm{~m}$ downwards, and from $8 \mathrm{~m}$ in June 2018. At the beginning of August 2018, oxygen conditions in the hypolimnion improved slightly. In October 2018, the autumn mixing began, and was completed in the beginning of December 2018. Ice cover appeared on the lake in the second half of January 2019 and lasted for only about a month. Reverse stratification then developed. After the lake had thawed, there was a spring mixing. The thermal stratification phase of the lake began in the first half of April 2019 already. The water measurements revealed substantial variations in temperature (up to $3.1^{\circ} \mathrm{C}$ ) in a short time (30 min) during the stratification period at the depth thermocline ( $8 \mathrm{~m})$ (Fig. 4B).

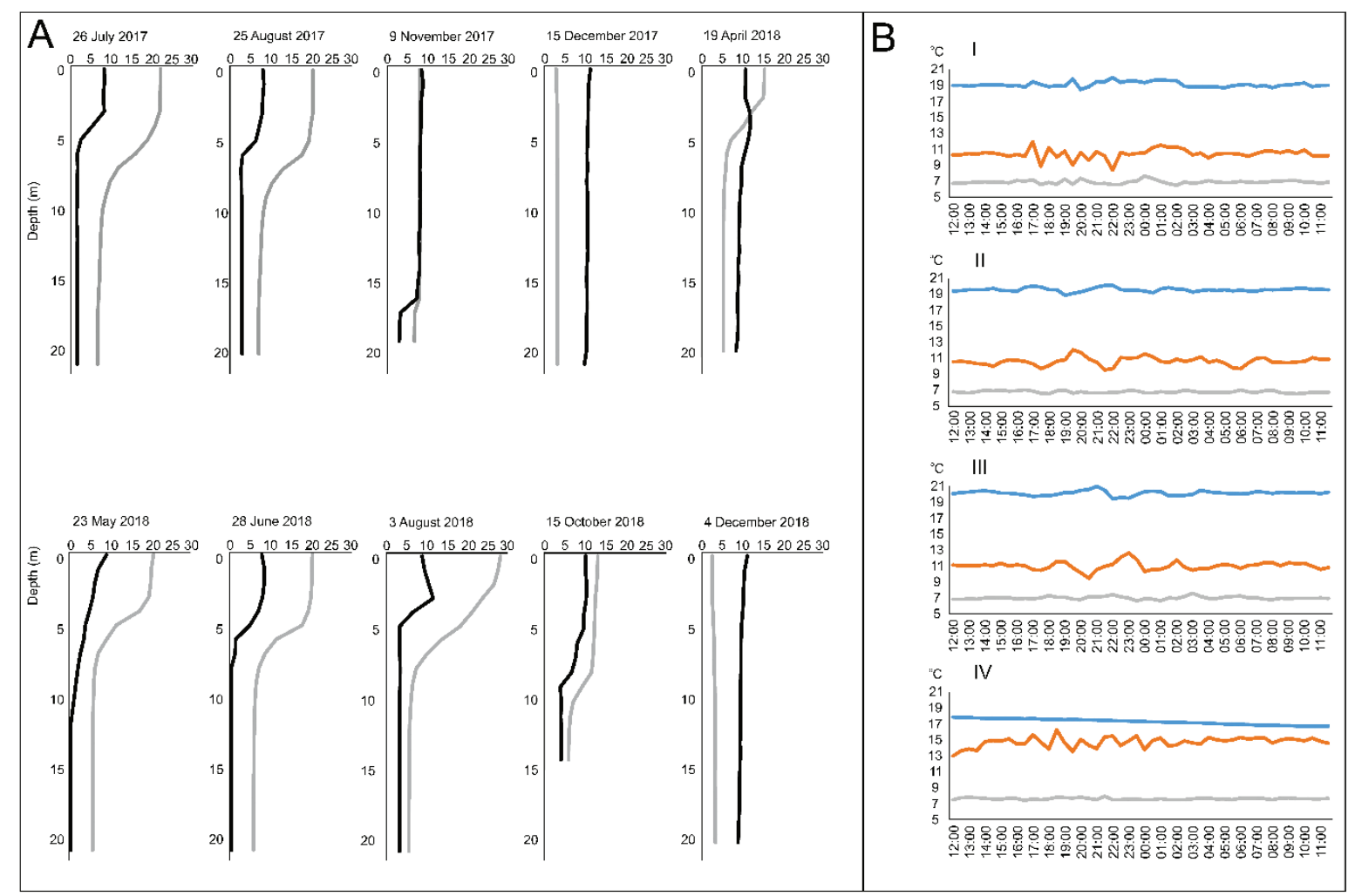

Figure 4. A: The water temperature in ${ }^{\circ} \mathrm{C}$ (gray line) and dissolved oxygen in $\mathrm{mg} \mathrm{dm}^{-3}$ (black line) in Lake Gościąz; B: selected examples of water temperature at $6 \mathrm{~m}$ (blue line), $8 \mathrm{~m}$ (orange line), $10 \mathrm{~m}$ (gray line) depth. I - 18.07.2018 (12:00) - 19.07.2018 (12:00); II - 25.07 .2018 (12:00) - 26.07.2018 (12:00); III $3.08 .2018(12: 00)$ - 4.08.2018 (12:00); IV - 24.09.2018 (12:00) - 25.09.2018 (12:00). 
Measurements of Secchi disc visibility determined that water transparency was lowest (about $1 \mathrm{~m}$ ) in early spring (March 2018 and April 2019). A noticeable increase in Secchi disc visibility was recorded in May (from $3.5 \mathrm{~m}$ to $5.0 \mathrm{~m}$ ). In summer and early autumn, the water transparency again decreased to $1.0-1.5 \mathrm{~m}$. After this period, Secchi disc visibility increased to $3 \mathrm{~m}$.

\subsection{Sedimentation cycle}

The qualitative analysis of 66 smear slides showed a clear seasonal variation in sample composition. In general, sample content in a given season was similar at all locations and both depths. The annual cycle started in spring, immediately after ice cover disappearance (Fig. 5). The spring sedimentation was dominated by phytoplankton appearance (diatoms) and followed by calcite (ca. 6-8 $\mu \mathrm{m})$ autochthonous precipitation. We also observed coarse $(>6-8 \mu \mathrm{m})$ but rare calcite agglomerates, which in contrary to fresh, single grains, could have been transported to the lake bottom through resuspension from the littoral zone. During summer, the amount of diatoms was very low in comparison to the number of zooplankton remains, which increased markedly. Fresh calcite grains were abundant. During the autumn, sediment was enriched with fresh calcite and its agglomerates and diatoms. However, the amount of diatoms was much lower than during the spring, which leads to a conclusion that the calcite was the main component of the retrieved sediment. Deposition of mineral matter (rare grains of quartz), scarce diatoms, fungi and remains of plant tissues prevailed in the winter. During the whole cycle, a green alga (Phacotus) with a calcite lorica was observed.

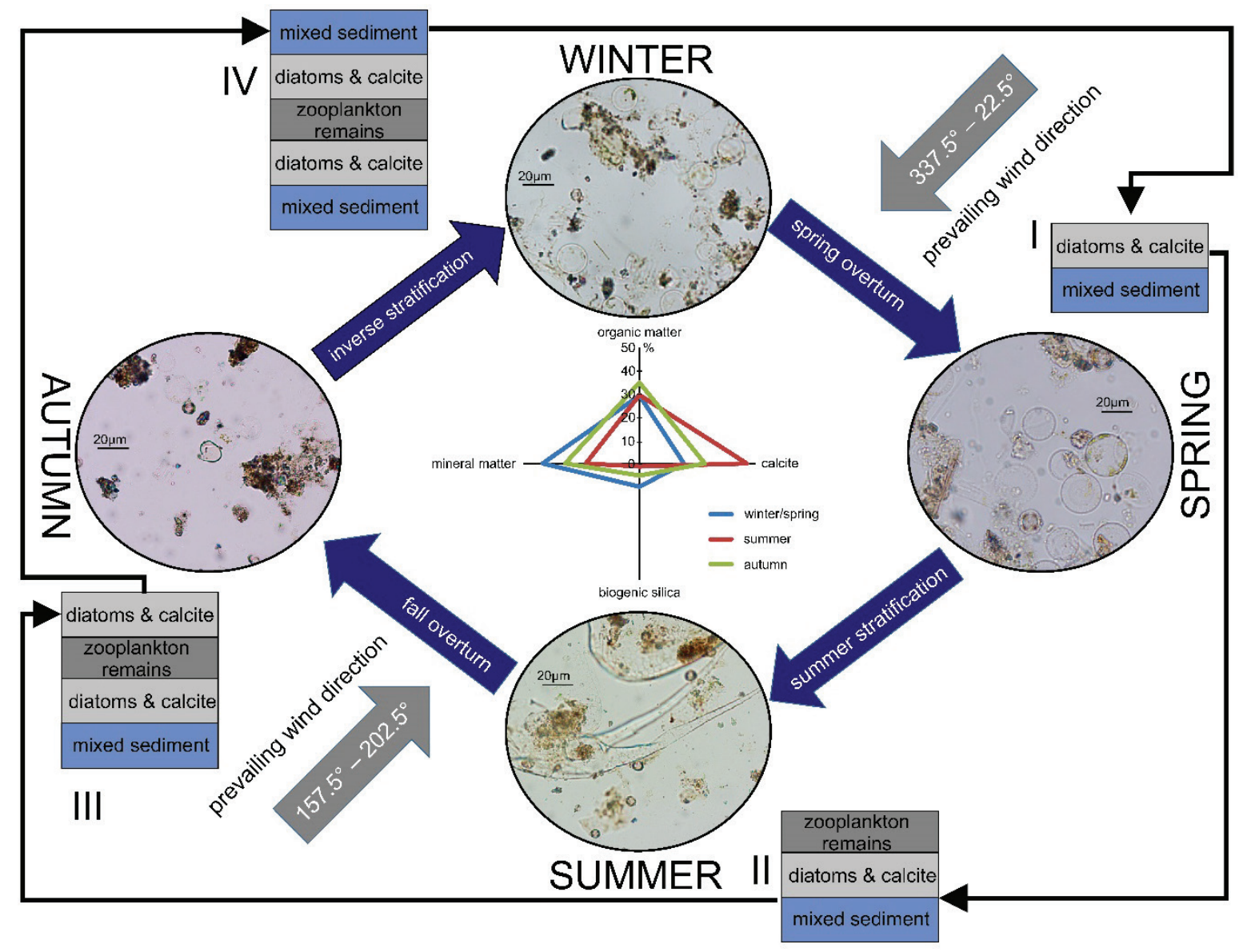

Figure 5. The seasonal changes within sedimentation cycle within Lake Gościąż. 
The smear slide analysis results are generally consistent with the results of the quantitative geochemical studies on the 57 sediment samples (Fig. 6). They showed that the tested sediments comprise $18.7-53.3 \%$ of organic matter (averaging 30.9\%) and $9.7-64.8 \%$ of calcium carbonate (averaging 28.7\%). The highest contribution of organic material was found in samples representing the summer and autumn months. Calcium carbonate sedimented mainly in summer (July, August). The lowest content of calcium carbonate was measured in samples taken in spring (April, May). Biogenic silica accounted for $0.4-27.3 \%$ (averaging $6.2 \%$ ) and terrigenous silica for $0.8-41 \%$ (averaging $14.5 \%$ ). Both forms of silica were most strongly represented in spring and autumn samples. The seasonal variability of the sediment composition was, however, very similar across all locations for particular measurement series. Against this background, however, the GOS 3A site stands out, as its sediments had a significantly higher content of terrigenous material and a lower content of calcium carbonate. The GOS 2 site was also particular, as, unlike the other two, it had a clearly greater vertical differentiation in biogenic silica content.
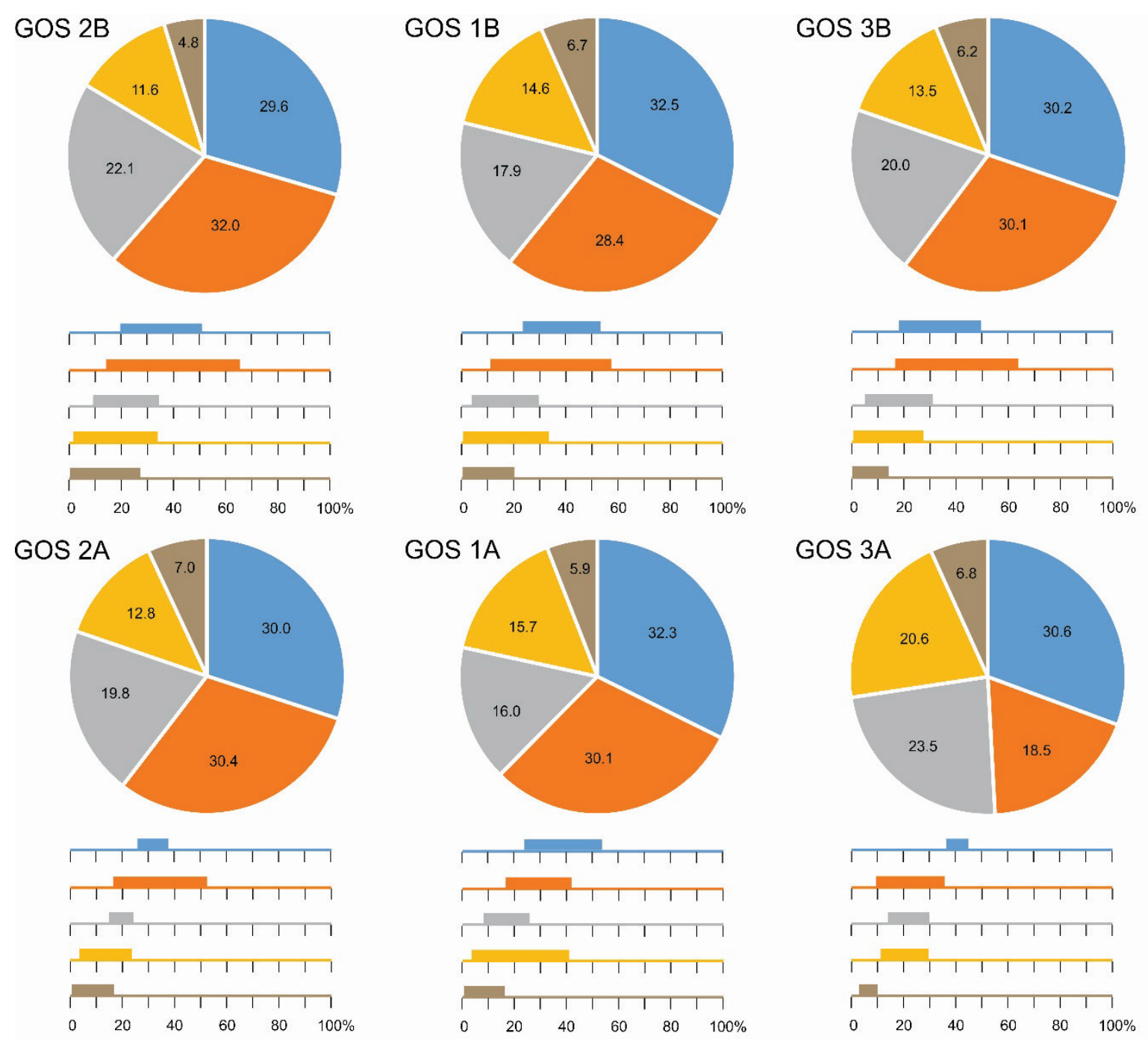

W
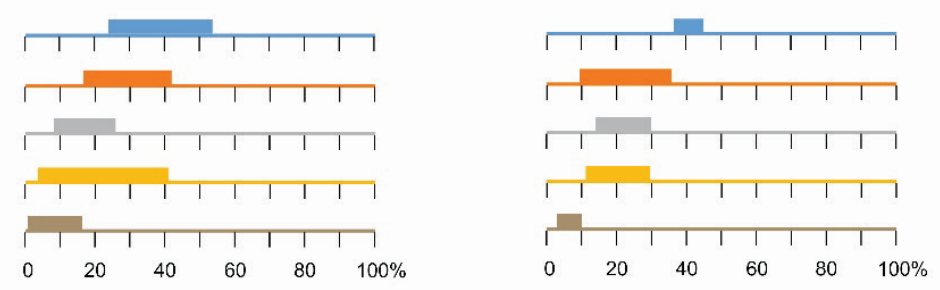

Figure 6. Properties of the sediment collected in the sedimentation traps in Lake Gościaż: average values and ranges (in percent). Organic matter (blue), calcium carbonate (orange), mineral residue (gray), terrigenous silica (yellow) and biogenic silica (brown). Epilimnion traps (GOS 2B, GOS 1B, GOS 3B), hypolimnion traps (GOS 2A, GOS 1A, GOS 3A). 


\section{Discussion}

\subsection{Spatial variation in sedimentation}

Previous studies on sediment accumulation rates have shown cases of sediment both decreasing with increasing depth (Bloesch and Uehlinger, 1986; Botwe et al., 2017) and the reverse (Kentzer and Żytkowicz, 1993; Ott et al., 2018). In almost all cases, our study results on contemporary sediment accumulation rates in Lake Gościąż showed the amount of material deposited in traps increasing with depth. The only case of sediment accumulation rate in a trap installed in the epilimnion (in the GOS 2B trap) being greater than that in the hypolimnion (GOS 2A) occurred in July 2018, and may have been caused by an increased concentration of phytoplankton in the western part of the lake. This should be associated with the effect of the surface water layer being pushed or displaced by a strong easterly wind (gusts of up to $7.5 \mathrm{~m} \mathrm{~s}^{-1}$ for 3 days) at the end of June 2018. During the lake mixing (early spring and autumn) differences in the amount of sediment between the traps in the hypolimnion (A traps) and those in the epilimnion (B traps) were largest. More than once, especially in autumn, the amount of sediment in the A traps was more than double that in the B traps. During the summer stratification, when a wellestablished thermocline is a natural barrier to falling sediment (Lastein, 1976; Mieszczankin, 2004), the differences between the traps in the epilimnion and those in the hypolimnion were smaller. Similar relationships were noted during the research conducted on Lake Gościąż in 1991 (Kentzer and Żytkowicz, 1993) and in 1993-95 (Mieszczankin, 2004). Then too, summer quantities of sediment were similar at various depths, while in spring, and especially in late autumn, the rate of accumulation in the hypolimnion was several times greater than that in the epilimnion. The higher rate of sedimentation during the lake's overturn should be associated with an increased proportion of material from resuspension (Mieszczankin, 2004).

Assuming that the volume of primary production is similar in various places in such a small lake, the spatial variation in the amount of sedimentation is determined by other factors. In the case of lakes fed by river discharge, the influence of the density currents on the course and the distribution of sedimentation is greater (Lewis et al., 2002; Cohen, 2003; Schiefer and Gilbert, 2008). The significance of this factor may be dismissed in the case of Lake Gościąż. The small inflow (the average annual discharge is about $13 \mathrm{dm}^{3} \mathrm{~s}^{-1}$ ), which disappears in summer and autumn, plays practically no role in supplying matter. In small, shallow lakes, this variability is mainly determined by the topography (Terasmaa, 2005) steepness of the lake basin (Blais and Kalff, 1995) and the distance of the measuring point from the shore (Bennett and Buck, 2016; Graham et al., 2016). Higher sediment accumulation rates are found in a lake's deepest places, and in positions closer to the littoral zone. This is also true of Lake Gościąż. The lake basin morphology favours this. It consists of two steep-sloped basins (Fig. 1) separated by a clear threshold. This kind of the topography means that the sediment accumulation rate at the GOS 1 and GOS 2 stations is markedly higher than at GOS 3. This can be attributed to a "funnel effect", which involves the stream of falling particles increasing in concentration, translated into a higher sediment accumulation rate in the steepest zones of the lake basin. Material from the shallower parts of the lake being supplied can also not be discounted. Particularly favourable conditions in terms of sedimentation rate occurred at the GOS 2 site. This is due to the specific features of the location. The most important are the good sheltered of the local pool and the proximity of the littoral zone. The distal location of the site is also important, as it favours the supply of material from shallower parts of the lake via the action of internal waves along the bottom. This last factor has a particularly large impact on the course of sedimentation at the GOS 3 site. The supply of material from the littoral zone to the sediment trap, which is in the hypolimnion, is evidenced by the high share of mineral material in the sediment composition (Fig. 6).

During the 1991 study, the sediment accumulation rate at the deepest point of the lake averaged $8.65 \mathrm{~g} \mathrm{~m}^{-2} \mathrm{~d}^{-1}$, while this value once reached $28.56 \mathrm{~g} \mathrm{~m}^{-2} \mathrm{~d}^{-1}$ (in October 1991). Sediment accumulation rate values in other months ranged from $1.84 \mathrm{~g} \mathrm{~m}^{-2} \mathrm{~d}^{-1}$ to $13.61 \mathrm{~g} \mathrm{~m}^{-2} \mathrm{~d}^{-1}$ (Kentzer and Żytkowicz, 1993) and were comparable with the 2017-19 results. This is indirect evidence that environmental conditions 
in the catchment are stable. Over the past 30 years there have been no changes in land use. Since 2001, Lake Gościąż's drainage basin has been protected as a reserve and human impact has been negligible. The form and structure of forest use has not changed in that time.

\subsection{Seasonal variation in sedimentation cycle and its potential for varve formation and preservation}

When examining the sediment accumulation rate in lakes, the local climate should be taken into consideration, since it may affect the seasonal variability of sedimentation. The amount of sediment can have either one or two peaks in a year and vary in duration. One commonly observed case is the clear increase in the amount of sediment in early spring. Sometimes this peak is persisted through the summer (Ott et al., 2018; Johansson et al., 2019). It can also happen that the peak occurs only in the summer (Bloesch and Uehlinger, 1986). Usually, however, two peaks - in early spring and autumn - can be found (Bonk et al., 2015; Ott et al., 2018). This last case applies to Lake Gościąż. The spring and autumn increase in sedimentation rate primarily result from increased primary production in the lake. This is favoured by the increase in air temperature in spring, the supply of nutrients from the lake bottom during periods of water mixing, and from the lake catchment in spring. According to our observations, a significant proportion of the material gathered in the sedimentation traps (especially traps in the hypolimnion) is redeposited from the lake basin.

The thermal conditions of Lake Gościąż are typical for dimictic water bodies. The temperature measurements showed clear thermal stratification from April 2018 to October 2018, and overturn in spring and autumn. Stratification and mixing periods significantly affect the amount of dissolved oxygen in the water column. Oxygen content is particularly important when considering the preservation of laminated sediments. For conditions to be conducive to preserving lamination, bottom waters should be devoid of, or relatively low in oxygen for at least part of the year (Anderson and Dean, 1988). The extent to which oxygen-free (anoxic) conditions are created is influenced by both how much organic matter is produced and the intensity of circulation in the water column (Kienel et al., 2013). The relatively short period of anoxia in Lake Gościąż (from May 2018 to July 2018) may have adversely affected the preservation of sediment lamination. Compared to studies from the 1990s, when anoxia lasted from May to October, anaerobic conditions now last considerably shorter. However, detailed investigation by Bonk et al. (2021) showed that the annual lamination can be recognised in the sediment structure up to coring time (2015 CE).

The increase in the dissolved oxygen concentration below the thermocline observed in July 2018 and August 2018 is probably attributable to temporary circulation introduced by internal waves. Internal waves drive baroclinic shear instabilities that enhance the vertical turbulent diffusivity and reduce the rate of dissolved oxygen depletion in the hypolimnion (Bouffard et al., 2014). Deep motions characterised by larger amplitudes at lower frequencies are favoured by the excitation of internal waves of the second vertical mode in strongly thermally stratified lakes (Valerio et al., 2019). Internal waves are a common response to wind forcing in not only large but also small stratified lakes (Boegman, 2009). Internal waves at the density discontinuity border along the course of the thermocline are a record of short-term water temperature variations in the metalimnion (Thorpe and Jiang, 1998; Pannard et al., 2011; Bonhomme et al., 2011; Filatov et al., 2012). Measurements taken in the middle of the lake (GOS 1) showed just such a temperature variability at a depth of $8 \mathrm{~m}$ (Fig. 4B). This can be considered indirect evidence of the occurrence of internal waves in Lake Gościąż.

In addition to the general effect that air temperature has on a lake's thermal and oxygen regimes, the short-term effects that meteorological parameters have on the hydrodynamic state of a lake should also be taken into account. In this regard, it is crucial to determine the effect of wind on lake mixing, the formation of internal waves, and the water circulation caused by their appearance. Increased water dynamics, not only in the epilimnion layer but also in the deeper layers of the lake, cause previously 
deposited sediment to be resuspended and increase the amount of material recorded in sedimentation traps. In Lake Gościąż, during the early spring and autumn, when the sediment accumulation rate increased, the prevailing winds were southerly and south-westerly. In the summer, when there was less sediment in the traps, northerlies prevailed. During prolonged strong winds, sedimentation increased, and in the GOS 2A trap in particular. When wind conditions were stable, the GOS 1A trap accumulated the most sediment, i.e. the one in the deepest studied location. The major impact of storm phenomena, when the strongest gusts were recorded, is visible in the course of sedimentation in the lake's western sub-basin (GOS 2A). The steep slope in the western part of the lake and the closeness of the sediment traps to the shore increased the supply of redeposition material. Internal waves formed under the influence of strong gusts of wind triggered the resuspension of material accumulated in the littoral zone and on the slope of the lake basin. The course of sedimentation was similar in the eastern part of the lake (GOS 3A), where the supply of material redeposited from the littoral zone is confirmed by the high content of terrigenous matter in the analysed samples.

The two-year investigation of lake productivity and weather conditions revealed clear, seasonal changes in sediment composition. Weather conditions have a direct influence on the water column, and thereby on variations in sediment composition. The sedimentation cycle starts when the ice cover begins to melt. Because the water density is uniform throughout the water column in that period, low wind speed is required to start the spring overturn (Löffler, 2004). Northerly winds $\left(337.5^{\circ}-22.5^{\circ}\right)$ were the most frequent in spring in both study years and could have caused the intensive water column mixing (Fig. 2). Smear slides analysis suggests that green algae developed rapidly in spring (Fig. 5). The increased abundance of phytoplankton and rising temperatures caused, in turn, authigenic calcite production (Groleau et al., 2000), which is visible in the increased $\mathrm{CaCO}_{3}$ content (Fig. 6). As the heating proceeded, a thermocline developed and caused the development of the summer stratification of waters.

After the summer stratification, the epilimnion cooled down and, as a result, the temperature was the same throughout the water column. In autumn, southerly $\left(157.5^{\circ}-202.5^{\circ}\right)$ and south-westerly $\left(202.5^{\circ}-247.5^{\circ}\right)$ winds dominated, which caused the mixing of the water column to the bottom. The mixing could be the reason for the higher deposition and may be related to the remobilisation of nutrients, so the nutrients accumulated in the hypolimnion may have reached the surface layer of water and caused the phytoplankton bloom.

Reworked calcite forms agglomerates, in contrast to the single calcite grains that are newly precipitated in biochemical processes. The resuspended calcite grains were first observed in spring next to fresh grains. However, they were most abundant during autumn. The appearance of phytoplankton along with both types of calcite suggests a second calcite precipitation event and supports the idea of previously deposited material having been remobilised. It is not possible, however, to distinguish whether the resuspended calcite represents littoral sediments or comes from deeper slopes of the lake.

The seasonality in the course of sedimentation is partly reflected in water transparency measurements. Under conditions of thermal stratification, when the sediment accumulation rate was lowest, water transparency was highest. By contrast, water transparency was lowest during lake mixes, and during the spring peak in primary production, when the sediment accumulation rate was higher.

In dealing with the various factors that might affect the seasonal distribution of sedimentation, it was also necessary to consider how the lake water level fluctuated throughout the year (Lopez et al., 2016). During the study period, however, this was minor, with the fluctuation amplitude not exceeding $40 \mathrm{~cm}$. The weir on the stream Ruda, downstream of Lake Gościąż, moderates water level fluctuations in the lake. In connection with the above, this factor has a negligible role in the course of contemporary sedimentation in this area. 


\section{Conclusions}

The results of this study show a spatio-temporal variation in sediment accumulation rate in the relatively small Lake Gościąż, Poland. The mean sediment accumulation rate in each of the three monitored locations was higher in the traps in the hypolimnion than in the traps in the epilimnion, as well as in locations with greater maximum depth. These results depend not so much on the spatial variation of the biological productivity of the lake, but mostly on the topography of the lake bottom (funnel effect). The seasonal variations were influenced by air temperature, and the speed and direction of the wind. These factors favoured the development of internal waves, which in turned caused an oxygen increase in the deeper parts of the lake. The confirmed relationship between sediment accumulation rate and both wind speed and direction indicates that relocated material is supplied to sediment traps, especially those located deeper. Redeposition of the material was also evidenced by the results of our analysis of smear slides and sediment composition. They showed that sediment composition is affected by season and the occurrence of strong north-westerly and south-westerly winds. The patterns and mechanisms of the course of contemporary sedimentation in Lake Gościąz, as determined based on the conducted investigations, can be applied in the study of other lakes and in assessing the representativeness of sampling sites for laminated bottom sediments to be used in palaeoenvironmental studies.

\section{Acknowledgments}

This study is a contribution to the scientific project financed by the National Science Centre, Poland - No. UMO-2015/19/B/ST10/03039 "New high-resolution and integrated analyses of environmental response to climate change over the last 15,000 years from the Lake Gościąż sediment record within the frame of a WE European transect". We would like to sincerely thank Sebastian Tyszkowski for making the bathymetric map of Lake Gościąż.

\section{References}

Anderson, R.Y., Dean, W.E. 1988. Lacustrine varve formation through time. Palaeogeography, Palaeoclimatology, Palaeoecology 62 (1-4), 215-235. https://doi.org/10.1016/0031-0182(88)90055-7

Bartczak, A., Słowińska, S., Tyszkowski, S., Kramkowski, M., Kaczmarek, H., Kordowski, J., Słowiński, M. 2019. Ecohydrological changes and resilience of a shallow lake ecosystem under intense human pressure and recent climate change. Water 11 (1), 32. https://doi.org/10.3390/w11010032

Bechtel, A., Woszczyk, M., Reischenbacher, D., Sachsenhofer, R.F., Gratzer, R., Püttmann, W., Spychalski, W. 2007. Biomarkers and geochemical indicators of Holocene environmental changes in coastal Lake Sarbsko (Poland). Organic Geochemistry 38 (7), 1112-1131. https://doi.org/10.1016/j.orggeochem.2007.02.009

Bennett, K.D., Buck, C.E. 2016. Interpretation of lake sediment accumulation rates. The Holocene 26 (7), 10921102. https://doi.org/10.1177/0959683616632880

Blais, J.M., Kalff, J. 1995. The influence of lake morphometry on sediment focusing. Limnology and Oceanography 40 (3), 582-588. https://doi.org/10.4319/lo.1995.40.3.0582

Bloesch, J., Uehlinger, U. 1986. Horizontal sedimentation differences in a eutrophic Swiss lake. Limnology and Oceanography 31 (5), 1094-1109. https://doi.org/10.4319/1o.1986.31.5.1094

Bluszcz, P., Kirilova, E., Lotter, A.F., Ohlendorf, C., Zolitschka, B. 2008. Global radiation and onset of stratification as forcing factors of seasonal carbonate and organic matter flux dynamics in a hypertrophic hardwater lake (Sacrower See, Northeastern Germany). Aquatic Geochemistry 14 (1): 73-98. https://doi.org/10.1007/s10498-008-9026-3

Boegman, L. 2009. Currents in stratified water bodies 2: Internal waves. In: G.E. Likens, (Ed.) Encyclopedia of Inland Waters. Volume 1. Elsevier, Oxford, pp. 539-558. 
Bonhomme, C., Poulin, M., Vinçon-Leite, B., Saad, M., Groleau, A., Jézéquel, D., Tassin, B. 2011. Maintaining meromixis in Lake Pavin (Auvergne, France): The key role of a sublacustrine spring. Comptes Rendus Geoscience 343 (11-12), 749-759. https://doi.org/10.1016/j.crte.2011.09.006

Bonk, A., Tylmann, W., Amann, B.J.F., Enters, D., Grosjean, M. 2015. Modern limnology and varve-formation processes in Lake Żabińskie, northeastern Poland: comprehensive process studies as a key to understand the sediment record. Journal of Limnology 74 (2), 358-370. https://doi.org/10.4081/jlimnol.2014.1117

Bonk, A., Kinder, M., Enters, D., Grosjean, M., Meyer-Jacob, C., Tylmann, W. 2016. Sedimentological and geochemical responses of Lake Żabińskie (north-eastern Poland) to erosion changes during the last millennium. Journal of Paleolimnology 56 (2-3), 239-252. https://doi.org/10.1007/s10933-016-9910-6

Bonk, A., Müller, D., Ramisch, A., Kramkowski, M., Noryśkiewicz, A.M., Sekudewicz, I., Gąsiorowski, M., Luberda-Durnaś, K., Słowiński, M., Schwab, M., Tjallingii, R., Brauer, A., Błaszkiewicz, M. 2021. Varve microfacies and chronology from a new sediment record of Lake Gościąż (Poland). Quaternary Science Review 251, 106715. https://doi.org/10.1016/j.quascirev.2020.106715

Botwe, B.O., Abril, J.M., Schirone, A., Barsanti, M., Delbono, I., Delfanti, R., Nyarko, E., Lens, P.N.L. 2017. Settling fluxes and sediment accumulation rates by the combined use of sediment traps and sediment cores in Tema Harbour (Ghana). Science of the Total Environment 609, 1114-1125. https://doi.org/10.1016/j.scitotenv.2017.07.139

Bouffard, D., Boegman, L., Ackerman, J.D., Valipour, R., Rao, Y.R. 2014. Near-inertial wave driven dissolved oxygen transfer through the thermocline of a large lake. Journal of Great Lakes Research 40 (2), 300307. https://doi.org/10.1016/j.jglr.2014.03.014

Choiński, A., Ptak, M., Skowron, R., Strzelczak, A. 2015. Changes in ice phenology on polish lakes from 1961 to 2010 related to location and morphometry. Limnologica 53, 42-49. https://doi.org/10.1016/j.limno.2015.05.005

Churski, Z., Marszelewski, W. 1998. Hydrology and sedimentation conditions in Lake Gościąż. In: M. RalskaJasiewiczowa (Ed.), Lake Gościąz, Central Poland: A Monographic Study, Part 1. W. Szafer Institute of Botany, Polish Academy of Sciences, Kraków, pp. 39-45.

Cohen, A.S. 2003. Paleolimnology: the history and evolution of lake systems. Oxford University Press, Oxford, $528 \mathrm{pp}$.

Dearing, J.A. 1997. Sedimentary indicators of lake-level changes in the humid temperate zone: a critical review. Journal of Paleolimnology 18 (1), 1-14. https://doi.org/10.1023/A:1007916210820

Demidowicz, G., Deputat, T., Górski, A., Zaliwski, E., Wróblewska, E. 1998. Numerical map of length of vegetation period. IUNG, Puławy. http://www.zazi.iung.pulawy.pl/Images/Maps/dl_oweg.jpg Accessed 12 Jul 2019.

Filatov, N., Terzevik, A., Zdorovennov, R., Vlasenko, V., Stashchuk, N., Hutter, K. 2012. Field Studies of NonLinear Internal Waves in Lakes on the Globe. In: K. Hutter (Ed.), Nonlinear internal waves in lakes. Springer, Berlin, Heidelberg, pp. 23-103. https://doi.org/10.1007/978-3-642-23438-5_2

Flower, R.J. 1990. Seasonal changes in sedimenting material collected by high aspect ratio sediment traps operated in a holomictic eutrophic lake. In: J.P. Smith, P.G. Appleby, R.W. Battarbee, J.A. Dearing, R. Flower, E.Y. Haworth, F. Oldfield, P.E. O’Sullivan (Eds.), Environmental History and Palaeolimnology. Springer, Dordrecht, pp. 311-316. https://doi.org/10.1007/978-94-011-3592-4_40

Gasith, A. 1976. Seston dynamics and tripton sedimentation in the pelagic zone of a shallow eutrophic lake. Hydrobiologia 51 (3), 225-231. https://doi.org/10.1007/BF00005748

Gierszewski, P. 2000. Charakterystyka środowiska hydrochemicznego wód powierzchniowych zachodniej części Kotliny Płockiej. Prace Geograficzne, 176, Instytut Geografii i Przestrzennego Zagospodarowania PAN, Warszawa, $136 \mathrm{pp}$.

Gierszewski, P. 2001. Variability of the concentration of chemical substances in the Ruda river-lake system (Płock Basin). Limnological Review 1, 83-93.

Giziński, A., Kentzer, A., Mieszczankin, T., Żbikowski, J., Żytkowicz, R. 1998. Hydrobiological characteristics and modern sedimentation of Lake Gościąż. In: M. Ralska-Jasiewiczowa (Ed.), Lake Gościąż, Central 
Poland: A Monographic Study, Part 1. W. Szafer Institute of Botany, Polish Academy of Sciences, Kraków, pp. 49-60.

Glazik, R. 1978. Wpływ zbiornika wodnego na Wiśle we Włocławku na zmiany stosunków wodnych w dolinie. Dokumentacja Geograficzna, 2-3, Instytut Geografii i Przestrzennego Zagospodarowania PAN, Warszawa, 119 pp.

Goslar, T., Kuc, T., Ralska-Jasiewiczowa, M., Różański, K., Arnold, M., Bard, E., van Geel, B., Pazdur, M.F., Szeroczyńska, K., Wicik, B., Więckowski, K., Walanus, A. 1993. High - resolution lacustrine record of the Late Glacial/Holocene transition in central Europe. Quaternary Science Review 12 (5), 287-294. https://doi.org/10.1016/0277-3791(93)90037-M

Graham, N.D., Bouffard, D., Loizeau, J.L. 2016. The influence of bottom boundary layer hydrodynamics on sediment focusing in a contaminated bay. Environmental Science and Pollution Research 23 (24), 2541225426. https://doi.org/10.1007/s11356-016-7715-9

Groleau, A., Sarazin, G., Vinçon-Leite, B., Tassin, B., Quiblier-Llobreas, C. 2000. Tracing calcite precipitation with specific conductance in a hard water alpine lake (Lake Bourget). Water Research 34 (17), 41514160. https://doi.org/10.1016/S0043-1354(00)00191-3

Heiri, O., Lotter, A.F., Lemcke, G. 2001. Loss on ignition as a method for estimating organic and carbonate content in sediments: reproducibility and comparability of results. Journal of Paleolimnology 25, 101-110. https://doi.org/10.1023/A:1008119611481

Horppila, J., Niemistö, J. 2008. Horizontal and vertical variations in sedimentation and resuspension rates in a stratifying lake - effects of internal seiches. Sedimentology 55 (5), 1135-1144. https://doi.org/10.1111/j.1365-3091.2007.00939.x

Johansson, M., Saarni, S., Sorvari, J. 2019. Ultra-high-resolution monitoring of the catchment response to changing weather conditions using online sediment trapping. Quaternary 2 (2), 18. https://doi.org/10.3390/quat2020018

Kaal, J., Cortizas, A.M., Rydberg, J., Bigler, C. 2015. Seasonal changes in molecular composition of organic matter in lake sediment trap material from Nylandssjön, Sweden. Organic Geochemistry 83-84, 253-262. https://doi.org/10.1016/j.orggeochem.2015.04.005

Kentzer, A., Żytkowicz, R. 1993. Warunki formowania współczesnych osadów dennych w jeziorze Gościąż. Polish Botanical Studies. Guidebook Series 8, 39-48.

Kępczyński, K., Noryśkiewicz, A. 1993. Współczesna szata roślinna kompleksu jezior 'Na Jazach'. Polish Botanical Studies. Guidebook Series 8, 29-38.

Kępczyński, K., Noryśkiewicz, A. 1998. Vegetation of the Gostynińskie Lake District. In: M. RalskaJasiewiczowa (Ed.), Lake Gościąż, Central Poland: A Monographic Study, Part 1. W. Szafer Institute of Botany, Polish Academy of Sciences, Kraków, pp. 29-33.

Kienel, U., Dulski, P., Ott, F., Lorenz, S., Brauer, A. 2013. Recently induced anoxia leading to the preservation of seasonal laminae in two NE-German lakes. Journal of Paleolimnology 50 (4), 535-544. https://doi.org/10.1007/s10933-013-9745-3

Kienel, U., Kirillin, G., Brademann, B., Plessen, B., Lampe, R., Brauer, A. 2017. Effects of spring warming and mixing duration on diatom deposition in deep Tiefer See, NE Germany. Journal of Paleolimnology 57 (1), 37-49. https://doi.org/10.1007/s10933-016-9925-z

Kruczkowska, B., Błaszkiewicz, M., Jonczak, J., Uzarowicz, Ł., Moska, P., Brauer, A., Bonk, A., Słowiński, M. 2020. The Late Glacial pedogenesis interrupted by aeolian activity in Central Poland - Records from the Lake Gościąż catchment. Catena 185, 104286. https://doi.org/10.1016/j.catena.2019.104286

Lastein, E. 1976. Recent sedimentation and resuspension of organic matter in eutrophic Lake Esrom, Denmark. Oikos 27 (1), 44-49. https://www.jstor.org/stable/3543430

Leemann, A., Niessen, F. 1994. Varve formation and the climatic record in an Alpine proglacial lake: calibrating annually-laminated sediments against hydrological and meteorological data. The Holocene 4 (1), 1-8. https://doi.org/10.1177/095968369400400101 
Lewis, T., Gilbert, R., Lamoureux, S.F. 2002. Spatial and temporal changes in sedimentary processes at proglacial Bear Lake, Devon Island, Nunavut, Canada. Arctic, Antarctic and Alpine Research 34 (2), 119-129.

Lopez, P., Lopez-Tarazon, J.A., Casas-Ruiz, J.P., Pompeo, M., Ordonez, J., Munoz, I. 2016. Sediment size distribution and composition in a reservoir affected by severe water level fluctuations. Science of the Total Environment 540, 158-167. https://doi.org/10.1016/j.scitotenv.2015.06.033

Lotter, A.F., Birks, H.J.B. 1997. The separation of the influence of nutrients and climate on the varve time-series of Baldeggersee, Switzerland. Aquatic Sciences 59 (4), 362-375. https://doi.org/10.1007/BF02522364

Löffler, H, 2004. The origin of lake basins. In: P.E. O'Sullivan, C.S. Reynolds, (Eds.), The lakes handbook, Volume 1: Limnology and Limnetic Ecology. Wiley, New York, pp. 8-60.

Maier, D.B., Gälman, V., Renberg, I., Bigler, C. 2018. Using a decadal diatom sediment trap record to unravel seasonal processes important for the formation of the sedimentary diatom signal. Journal of Paleolimnology 60 (2), 133-152. https://doi.org/10.1007/s10933-018-0020-5

Mieszczankin, T. 1997. A spacio-temporal pattern of pollen sedimentation in a dimictic lake with laminated sediments. Water, Air, and Soil Pollution 99, 587-592. https://doi.org/10.1007/BF02406897

Mieszczankin, T., Noryśkiewicz, B. 2000. Processes that can disturb the chronostratigraphy of laminated sediments and pollen deposition. Journal of Paleolimnology 23 (2), 129-140. https://doi.org/10.1023/A:1008074701468

Mieszczankin, T. 2004. Procesy sedymentacji tryptonu w jeziorze Gościąż - warunki formowania współczesnych osadów dennych oraz rola tryptonu w transformacji i kumulacji fosforu. In: B. Głogowska, A. Kentzer (Eds.), Hydrobiologia toruńska: monografia dorobku prac doktorskich Zakładu Hydrobiologii w latach 1978-2003. Toruń, pp. 117-127.

Moore, J.J., Hughen, K.A., Miller, G.H., Overpeck, J.T. 2001. Little Ice Age recorded in summer temperature reconstruction from varved sediments of Donard Lake, Baffin Island, Canada. Journal of Paleolimnology 25 (4), 503-517. https://doi.org/10.1023/A:1011181301514

Müller, D., Tjallingii, R., Płóciennik, M., Luoto, T.P., Kotrys, B., Plessen, B., Ramisch, A., Schwab, M.J., Błaszkiewicz, M., Słowiński, M., Brauer, A. [in press]. New insights into lake responses to rapid climate change: The Younger Dryas in Lake Gościąż, Central Poland. Boreas

O'Sullivan, P.E. 1983. Annually laminated lake sediments and the study of Quaternary environmental changes a review. Quaternary Science Review 1 (4), 245-313. https://doi.org/10.1016/0277-3791(83)90008-2

Ojala, A.E.K., Heinsalu, A., Kauppila, T., Alenius, T., Saarnisto, M. 2008. Characterizing changes in the sedimentary record in southern central Finland around 8000 cal. yr BP. Journal of Quaternary Science 23 (8), 765-775. https://doi.org/10.1002/jqs.1157

Ojala, A.E.K., Francus, P., Zolitschka, B., Besonen, M., Lamoureux, S.F. 2012. Characteristics of sedimentary varve chronologies - a review. Quaternary Science Review 43, 45-60. https://doi.org/10.1016/j.quascirev.2012.04.006

Ojala, A.E.K., Bigler, C., Weckström, J. 2014. Understanding varved formation processes from sediment trapping and limnological monitoring. Past Global Changes Magazine $22 \quad$ (1), 8-9. https://doi.org/10.22498/pages.22.1.8

Ott, F., Dräger, N., Brykała, D., Kienel, U., Gierszewski, P., Plessen, B., Schwab, M.J., Brademann, B., Pinkerneil, S., Słowiński, M., Błaszkiewicz, M., Brauer, A. 2017. Deciphering varve formation in Lake Czechowskie (N Poland) and Lake Tiefer See (NE Germany) through comprehensive lake monitoring. In: M.J. Schwab, M. Błaszkiewicz, T. Raab, M. Wilmking, A. Brauer (Eds.) ICLEA Final Symposium 2017. Climate Change, Human Impact and Landscape Evolution in the Southern Baltic Lowlands. Abstract Volume \& Excursion Guide. Scientific Technical Report STR17/03. Potsdam, pp. 132-134.

Ott, F., Kramkowski, M., Wulf, S., Plessen, B., Serb, J., Tjallingii, R., Schwab, M., Słowiński, M., Brykała, D., Tyszkowski, S., Putyrskaya, V., Appelt, O., Błaszkiewicz, M., Brauer, A. 2018. Site-specific sediment responses to climate change during the last 140 years in three varved lakes in Northern Poland. The Holocene 28 (3), 464-477. https://doi.org/10.1177/0959683617729448 
Pace, M.L., Lovett, G.M. 2013. Primary production: the foundation of ecosystems. In: K. Weathers, D. Strayer, G. Likens (Eds.), Fundamentals of ecosystem science. Academic Press, pp. 27-51.

Pannard, A., Beisner, B.E., Bird, D.F., Braun, J., Planas, D., Bormans, M. 2011. Recurrent internal waves in a small lake: Potential ecological consequences for metalimnetic phytoplankton populations. Limnology and Oceanography 1 (1), 91-109. https://doi.org/10.1215/21573698-1303296

Peel, M.C., Finalyson, B.L., Mcmahon, T.A. 2007. Updated world map of the Köppen-Geiger climate classification. Hydrology and Earth System Science 11 (5), 1633-1644. https://doi.org/10.5194/hess-111633-2007

Petterson, G., Renberg, I., Geladi, P., Lindberg, A., Lindgren, A. 1993. Spatial uniformity of sediment accumulation in varved lake sediments in northern Sweden. Journal of Paleolimnology 9 (3), 195-208. https://doi.org/10.1007/BF00677213

Punning, J.M., Alliksaar, T., Terasmaa, J., Jevrejeva, S. 2004. Recent patterns of sediment accumulation in a small closed eutrophic lake revealed by the sediment records. Hydrobiologia 529 (1-3), 71-81. https://doi.org/10.1007/s10750-004-4948-2

Ralska-Jasiewiczowa, M., Goslar, T., Madeyska, T., Starkel, L. (Eds.). 1998. Lake Gościąż, Central Poland: A Monographic Study, Part 1. W. Szafer Institute of Botany, Polish Academy of Sciences, Kraków, 340 pp.

Ruttner, F, 1963. Fundamentals of Limnology. University of Toronto, Toronto, 295 pp.

Rychel, J., Błaszkiewicz, M., Brykała, D., Gierszewski, P., Lisicki, S., Roman, M., Tyszkowski, S. 2014, Mapa geologiczno-turystyczna Gostynińsko-Włocławskiego Parku Krajobrazowego. Państwowy Instytut Geologiczny - PIB, Instytut Geografii i Przestrzennego Zagospodarowania PAN, Uniwersytet Łódzki, Warszawa.

Rychel, J., Woronko, B., Błaszkiewicz, M., Karasiewicz, T. 2018. Aeolian processes records within last glacial limit areas based on the Płock Basin case (Central Poland). Bulletin of the Geological Society of Finland 90 (2), 223-237. https://doi.org/10.17741/bgsf/90.2.007

Salminen, S., Saarni, S., Tammelin, M., Fukmoto, Y., Saarinen, T. 2019. Varve distribution reveals spatiotemporal hypolimnetic hypoxia oscillations during the past 200 years in Lake Lehmilampi, Eastern Finland. Quaternary 2 (2), 20. https://doi.org/10.3390/quat2020020

Schaller, T., Moor, H.C., Wehrli, B. 1997. Sedimentary profiles of Fe, Mn, V, Cr, As and Mo as indicators of benthic redox conditions in Baldeggersee. Aquatic Sciences 59 (4), 345-361. https://doi.org/10.1007/BF02522363

Schettler, G., Liu, Q., Mingram, J., Stebich, M., Dulski, P. 2006. East - Asian monsoon variability between 15,000 and 2000 cal. yr BP recorded in varved sediments of Lake Sihailongwan (northeastern China, Long Gang volcanic field). The Holocene 16 (8), 1043-1057. https://doi.org/10.1177/0959683606069388

Schiefer, E., Gilbert, R. 2008. Proglacial sediment trapping in recently formed Silt Lake, upper Lillooet Valley, Coast Mountains, British Columbia. Earth Surface Processes and Landforms 33 (10), 1542-1556. https://doi.org/10.1002/esp.1625

Schnurrenberger, D., Russell, J., Kelts, K. 2003. Classification of lacustrine sediments based on sedimentary components. Journal of Paleolimnology 29 (2), 141-154.

Segerström, U., Renberg, I., Wallin, J.E. 1984. Annual sediment accumulation and land use history; investigations of varved lake sediments: With 7 figures in the text. Internationale Vereinigung für theoretische und angewandte Limnologie: Verhandlungen 22 (3), 1396-1403. https://doi.org/10.1080/03680770.1983.11897507

Skompski, S. 1969. Stratygrafia osadów czwartorzędowych wschodniej części Kotliny Płockiej. Biuletyn Instytutu Geologicznego 220, 175-258.

Terasmaa, J. 2005. Bottom topography and sediment lithology in two small lakes in Estonia. Proceedings of the Estonian Academy of Sciences. Biology. Ecology 54 (3), 171-189.

Thorpe, S.A., Jiang, R. 1998. Estimating internal waves and diapycnal mixing from conventional mooring data in a lake. Limnology and Oceanography 43 (5), 936-945. https://doi.org/10.4319/lo.1998.43.5.0936 
Tylmann, W. 2011. Jeziorne osady rocznie laminowane w północnej Polsce: aktualny stan rozpoznania, postępy metodyczne i perspektywy badawcze. Studia Limnologica et Telmatologica 5 (1), 23-41.

Tylmann, W., Szpakowska, K., Ohlendorf, C., Woszczyk, M., Zolitschka, B. 2012. Conditions for deposition of annually laminated sediments in small meromictic lakes: a case study of Lake Suminko (northern Poland). Journal of Paleolimnology 47 (1), 55-70. https://doi.org/10.1007/s10933-011-9548-3

Urbaniak, U. 1966. Skład mineralny piasków wydmowych w Kotlinie Płockiej. Przegląd Geograficzny 38 (3), 435-453.

Valerio, G., Pilotti, M,. Lau, M.P, Hupfer, M. 2019. Oxycline oscillations induced by internal waves in deep Lake Iseo. Hydrology and Earth System Sciences 23 (3), 1763-1777. https://doi.org/10.5194/hess-23-17632019

Vos, H., Sanchez, A., Zolitschka, B., Brauer, A., Negedank, J.F.W. 1997. Solar activity variations recorded in varved sediments from the crater Lake of Holzmaar - a maar lake in the Westeifel volcanic field, Germany. Surveys in Geophysics 18 (2-3), 163-182. https://doi.org/10.1023/A:1006531825130

Wetzel, R.G., Rich, P.H., Miller, M.C., Allen, H.L. 1972. Metabolism of dissolved and particulate detrital carbon in a temperate hard water lake. Michigan State University, Hickory Corners, 109 pp. https://doi.org/10.2172/4614952

Wiśniewski, E. 1976. Rozwój geomorfologiczny doliny Wisty pomiędzy Kotlina Płocka a Kotlina Toruńską. Prace Geograficzne, 119, Instytut Geografii i Przestrzennego Zagospodarowania PAN, Warszawa, 124 pp.

Woszczyk, M., Cieślinski, R., Spychalski, W. 2009. Geochemistry of surface sediments of a costal Lake Sarbsko (Northern Poland). Studia Quaternaria, 26, 41-53.

Woś, A. 1999. Klimat Polski. Wydawnictwo Naukowe PWN, Warszawa, 301 pp.

Zolitschka, B., Francus, P., Ojala, A.E.K., Schimmelmann, A. 2015. Varves in lake sediments - a review. Quaternary Science Review 117, 1-41. https://doi.org/10.1016/j.quascirev.2015.03.019 